\title{
Evaluasi Kinerja Badan Pengelola Keuangan dan Aset Daerah Kota Padang Menurut Perspektif Balanced Scorecard
}

\author{
Diga Putri Oktaviane \\ Universitas Mohammad Natsir, Bukittinggi \\ lingga091086@gmail.com
}

\begin{abstract}
Each public sector organization was given an annual budget by the government which was used based on the programs launched, so that the vision and mission of the organization could be achieved properly. So far, the evaluation of organizational performance was assessed only on the basis of financial aspects, through financial reports that were provided annually by related agencies or agencies to the Padang City government and similar things were also carried out by the Regional Financial and Asset Management Agency of Padang City. Meanwhile, to assess whether a performance was good or not, it must also be measured based on other criteria, such as performance evaluation using the balanced scorecard method. This research was conducted through a descriptive study with a qualitative approach. Data collection techniques used in this study were interviews and documentation studies. The technique used to measure employee performance was balance scorecard method. Then the data were analysed through manual data analysis procedure. The results showed that in terms of budget management, the Padang City Financial and Asset Management Agency has not fully implemented the balance scorecard method in its performance.
\end{abstract}

Keywords: Management Revenue of Finance and Asset, Evaluation, Performance, Balanced Scorecard

How to Cite: Oktavianne, Diga Putri. 2021. Evaluasi Kinerja Badan Pengelola Keuangan dan Aset Daerah Kota Padang Menurut Perspektif Balanced Scorecard. Vol 5 (1): pp. 108-122. DOI: https://doi.org/10.24036/jess.v5i1

\section{Pendahuluan}

Semenjak otonomi daerah diberlakukan di Indonesia pada tahun 1999 yang ditandai dengan dikeluarkannya Undang-Undang Nomor 22 Tahun 1999 tentang sistem pemerintah daerah, maka sejak itu pemerintah daerah diberikan kewenangan untuk mengurus rumah tangga daerahnya sendiri atau otonomi daerah. Pada hakikatnya pemberian otonomi daerah dimaksudkan untuk memanifestasikan keinginan daerah dalam mengatur dan mengaktualisasikan seluruh potensi daerahnya secara maksimal, sehingga dapat meningkatkan kesejahteraan masyarakat di daerah. Menurut Agustina (2013) dalam otonomi daerah terdapat dua aspek kinerja keuangan yang dituntut agar lebih baik dibandingkan sebelum otonomi daerah. Aspek pertama adalah daerah diberi kewenangan mengurus pembiayaan daerah dengan kekuatan utama pada kemampuan Pendapatan Daerah (PAD). Aspek kedua yaitu di sisi manajemen, agar lebih efektif dan efisien dalam pengeluaran daerah. 
Pemerintah memiliki tiga fungsi yaitu fungsi pelayanan, fungsi pembangunan dan fungsi pemerintahan umum. Penyelenggaraan fungsi pemerintahan akan terlaksana apabila diikuti dengan pemberian sumber-sumber pendanaan berdasarkan kewenangan Pemerintah Pusat, Desentralisasi, Dekonsentrasi, dan Tugas Pembantuan, penerimaan yang cukup kepada daerah dengan mengacu kepada Undang-Undang Nomor 33 tahun 2004 tentang Perimbangan Keuangan Pusat dan Daerah. Dalam Undang-Undang Nomor 17 Tahun 2003 Pasal 6 tentang Keuangan Negara dijelaskan bahwa kekuasaan pengelolaan keuangan Negara dilakukan oleh Presiden selaku Kepala Pemerintahan, yang dikuasakan kepada Menteri Keuangan selaku pengelola fiskal dan wakil pemerintah dalam kepemilikan kekayaan Negara yang dipisahkan, dikuasakan kepada kementerian Negara atau lembaga yang dipimpinnya, diserahkan kepada Gubernur atau Bupati atau Walikota selaku kepala pemerintahan daerah untuk mengelola keuangan daerah dan mewakili pemerintahan daerah dalam kepemilikan kekayaan negara yang dipisahkan. Hal ini berarti pengelolaan keuangan daerah diserahkan kepada pemerintah di masing- masing daerah di Indonesia dan hal itu juga sesuai dengan Undang-Undang pemerintahan daerah yang berlaku saat ini yaitu UU Nomor 23 tahun 2014.

Dengan demikian, pemerintah daerah diberi kebebasan untuk mengelola keuangan dan kekayaan di daerahnya sendiri. Kewenangan pemerintah daerah dalam mengelola keuangan daerah antara lain diatur dalam Permendagri Nomor 13 tahun 2006 ini meliputi kekuasaan pengelolaan keuangan daerah, azas umum dan struktur APBD, penyusunan rancangan APBD, penetapan APBD, penyusunan dan penetapan APBD bagi daerah yang belum memiliki DPRD, pelaksanaan APBD, perubahan APBD, pengelolaan kas, penatausahaan keuangan daerah, akuntansi keuangan daerah, pertanggungjawaban pelaksanaan APBD, pembinaan dan pengawasan pengelolaan keuangan daerah, kerugian daerah, dan pengelolaan keuangan BLUD. Semua itu merupakan tugas dari Badan Pengelola Keuangan dan Aset Kota Daerah (BPKAD), termasuk BPKAD Kota Padang, yang memiliki dua fungsi sebagai Satuan Kerja Perangkat Daerah (SKPD) dan Satuan Kerja Pengelolaan Keuangan Daerah (SKPKD), Pelaksanaannya diatur berdasarkan Peraturan Menteri Dalam Negeri Nomor 13 Tahun 2006 tentang Pedoman Pengelolaan Keuangan Daerah dan Peraturan Daerah Kota Padang Nomor 16 Tahun 2008 tentang Pembentukan Organisasi dan Tata Kerja Dinas Kota Padang.

BPKAD Kota Padang memiliki visi yaitu terwujudnya pengelolaan keuangan yang akuntabel dan professional untuk mendukung pembangunan daerah. Sementara itu misi dari BPKAD ini adalah meningkatkan kualitas pelayanan administrasi, kinerja pengelolaan keuangan berbasis Teknologi Informasi dan profesionalitas sumber daya aparatur, meningkatkan sistem pengelolaan dan penatausahaan APBD yang efektif, efisien, transparan dan professional dalam mendukung pembangunan daerah, mewujudkan penatausahaan dan pengelolaan aset daerah yang professional, efisien dan efektif, meningkatkan kualitas penyusunan dan pelaporan keuangan daerah berbasis standar akuntansi pemerintah dan peraturan perundangan.

Tujuan pengelolaan keuangan daerah yaitu mengurus dan mengatur keuangan daerah itu sendiri dengan prinsip-prinsip pengelolaan keuangan daerah yang 
bertanggung jawab, mampu memenuhi kewajiban keuangan, kejujuran, efektif dan efisien serta pengendalian (Pekei, 2016). Dalam pengelolaan keuangan daerah, ada unsur-unsur yang berperan penting yaitu sistem atau cara pengelolaan keuangan daerah secara berdaya guna dan berhasil guna serta adanya kemampuan aparatur pengelola keuangan daerah sesuai kebutuhan tiap unit atau satuan kerja dalam pengelolaan keuangan daerah tersebut. Sama halnya dengan operasi perangkat daerah lainnya, bahwa setiap awal tahun setiap organisasi perangkat daerah diberikan anggaran untuk dikelola masing-masing instansi tersebut termasuk BPKAD agar dapat mencapai visi dan misi yang telah direncanakan sebelumnya.

Sementara dalam kenyataannya sampai saat ini visi BPKAD Kota Padang belum bisa terealisasikan dengan baik karena dalam pengelolaan anggaran tersebut masih banyak permasalahan yang muncul seperti sumber daya manusia aparatur yang mempunyai kompetensi pengelolaan keuangan daerah dan asset daerah masih terbatas, masih terdapat perbedaan persepsi dalam menafsirkan peraturan dengan badan pemeriksa keuangan (BPK), sarana dan prasarana yang kurang memadai, adanya gangguan sistem aplikasi informasi pengelolaan keuangan pendapatan dan asset, penempatan aparatur yang tidak sesuai dengan beban kerja, belum optimalnya kapasitas kelembagaan antara lain struktur, tupoksi, indikator kinerja utama kelembagaan dan prosedur kerja yang dapat mendukung peningkatan kinerja BPKAD, masih terdapat hal-hal mengenai pengelolaan keuangan dan asset daerah yang belum diatur dalam bentuk produk hukum daerah,belum adanya prosedur operasi baku, penyusunan anggaran belum berbasis kinerja, belum tertibnya penyajian data dan informasi, pengelola keuangan SKPD belum tertib dan terampil.

Untuk mencapai tujuan visi dan misi yang sudah dituangkan dalam Renstra BPKAD 2014-2019 sangat dibutuhkan strategi yang tepat. Salah satunya yaitu dengan penilaian kinerja. Selama ini penilaian kinerja hanya berdasarkan Laporan Akuntabilitas Kinerja (LAKIP) saja namun dalam kenyataannya LAKIP tersebut tidak bisa menjadi acuan bahwa kinerja organisasi tersebut dinilai baik atau tidak. Karena itu dibutuhkan pengukuran kinerja yang tidak hanya menilai dari sisi keuangan saja namun juga non keuangan. Maka dari itu peneliti mencoba melakukan evaluasi kinerja Badan Pengelolaan Keuangan dan aset ini berdasarkan balanced scorecard yang menggunakan empat perspektif. Hal ini dilakukan dengan menyebarkan angket kepada OPD yang membutuhkan pelayanan ke BPKA dan kepada pegawai yang ada di BPKA tersebut. Berdasarkan latar belakang tersebut, peneliti melakukan penelitian ini yang berjudul "Evaluasi Kinerja Badan Pengelola Keuangan Aset Daerah Kota Padang dengan Metode Balanced Scorecard".

\section{Tinjauan Kepustakaan}

\section{Pengelolaan Keuangan Daerah}

Dalam Peraturan Pemerintah Nomor 58 tahun 2005. Keuangan daerah adalah semua hak dan kewajiban daerah dalam rangka penyelenggaraan pemerintahan daerah yang dapat dinilai dengan uang termasuk di dalamnya segala bentuk kekayaan yang berhubungan dengan hak dan kewajiban daerah tersebut. Sementara itu, Yasin (2008) mengatakan bahwa keuangan daerah merupakan segala hak dan 
kewajiban pemerintah daerah untuk mengelola berbagai sumber keuangannya baik berupa uang maupun barang dalam rangka pelaksanaan desentralisasi.

Adisasmita (dalam Suoth et al., 2016) mengatakan bahwa anggaran mempunyai tiga kegunaan pokok yaitu sebagai pedoman kerja, sebagai alat pengkoordinasian kerja, dan sebagai alat pengawasan kerja. Pengelolaan Keuangan Daerah adalah program kerja suatu daerah dalam bentuk angka-angka dengan menyusun, merencanakan, melaksanakan, melaporkan, pertanggungjawaban dan pengawasan terhadap keuangan daerah berkaitan dengan Anggaran Pendapatan dan Belanja Daerah (Halim, 2001).

Pokok-pokok pengelolaan keuangan daerah pada dasarnya sama dengan pengelolaan keuangan Negara, yang terdiri atas tiga tahapan yaitu: (a) perencanaan APBD (b) pelaksanaan APBD, dan (c) pengendalian APBD. Pencapaian suatu tujuan kenegaraan perlu dilakukan oleh pemerintahan dengan baik mulai dari bawah yaitu pemerintah daerah, maka tujuan pengelolaan keuangan daerah berarti mengurus dan mengatur keuangan daerah itu sendiri dengan prinsip-prinsip pengelolaan keuangan daerah adalah sebagai berikut: a) tanggung jawab, b) mampu memenuhi kewajiban keuangan, dan c) kejujuran, d) efektif dan efisien, e) pengendalian (Halim, 2001).

Tantangan yang berpengaruh terhadap pelaksanaan pengelolaan keuangan daerah terbagi atas dua yaitu dilihat dari aspek masyarakat dan aspek sumber daya manusia. Kondisi masyarakat yang semakin kritis terhadap perubahan merupakan salah satu tantangan yang dihadapi pemerintah saat ini, karena tuntutan masyarakat terhadap pemerintah untuk mendapatkan peningkatan pelayanan dan kesejahteraan. Aspek sumber daya manusia ditunjukkan dengan adanya kemampuan aparat pengelola walaupun belum memadai dalam jumlah sesuai dengan kebutuhan tiap unit atau satuan kerja daerah tetapi dalam pengelolaan keuangan daerah dapat memberikan pelayanan yang sebaik mungkin kepada masyarakat. Hal ini dapat dilihat dari kontribusi penerimaan daerah sendiri dan tingkat efektifitas dan efisiensi yang semakin meningkat tiap tahun anggaran namun perlu ada pembenahan dalam arti daerah harus lebih baik lagi mulai dari proses rekrutmen pegawai sampai pada pemberian pelatihan terhadap aparatur sesuai dengan kebutuhan daerah tersebut.

\section{Balanced Scorecard dalam Pengelolaan Keuangan Daerah}

Balanced scorecard pada awalnya dikembangkan oleh Robert S. Kaplan dan David P. Norton sebagai alat pengukuran kinerja yang digunakan untuk perusahaanperusahaan bisnis komersil (Kaplan and Norton, 2001). Evaluasi kinerja dilakukan dengan cara membandingkan rencana skor yang hendak diwujudkan dengan hasil kinerja yang dicapai. Kartu skor untuk mengukur kinerja tersebut juga memiliki sifat berimbang. Artinya terdapat keseimbangan ukuran kinerja, yaitu antara ukuran finansial dengan nonfinansial, antara ukuran internal dan eksternal, antara kinerja jangka pendek dan jangka panjang. Kaplan dan Norton (dalam Dorf and Raitanen, 2005) menyatakan bahwa kelemahan-kelemahan pengukuran kinerja yang menitik beratkan pada kinerja keuangan yaitu ketidakmampuan mengukur kinerja harta yang tidak tampak (intangible assets) dan harta-harta intelektual perusahaan, kinerja keuangan hanya mampu menceritakan mengenai sedikit masa lalu 
perusahaan dan tidak mampu sepenuhnya menuntun perusahaan ke arah yang lebih baik.

Kerangka balanced scorecard tidak terbatas untuk organisasi bisnis akan tetapi organisasi sektor publik dapat menggunakannya dengan penempatan tumpuan yang berbeda. Melalui BSC, organisasi pemerintah atau sektor publik akan mampu menjelaskan misinya kepada masyarakat dan dapat mengidentifikasi indikator kepuasan masyarakat secara lebih transparan, objektif, dan terukur serta mampu mengidentifikasi proses kerja dan kualitas sumber daya manusia yang dibutuhkannya dalam mencapai misi dan strateginya (Nor, 2012)

Metode balanced scorecard yang digunakan untuk mengukur kinerja sektor publik dengan pendekatan yang dimiliki, Halim (dalam Mizkan et al., 2015) yaitu menilai kinerja dengan cara sebagai berikut: Pertama, dari perspektif pelanggan dilihat dari pemenuhan kepuasan masyarakat melalui penyediaan barang dan pelayanan publik. Kedua, perspektif keuangan ukuran kinerja yang digunakan seperti pertumbuhan ekonomi, pertumbuhan pajak, penghematan anggaran, dan indikator lain terkait dengan kinerja organisasi. Ketiga, perspektif proses internal yaitu dengan cara peningkatan proses layanan, perbaikan siklus layanan, peningkatan kapasitas infrastruktur, pemutakhiran teknologi dan pengintegrasian proses layanan. Dan yang terakhir, perspektif pertumbuhan dan pembelajaran yang melihat kinerja sektor publik berdasarkan seberapa besar kemampuan pemerintah daerah dalam mempertahankan dan meningkatkan keberhasilan yang telah dicapai dari periode ke periode berikutnya seperti peningkatan keahlian pegawai, peningkatan komitmen pegawai, peningkatan kemampuan membangun jaringan dan motivasi pegawai. Ukuran kinerja dari perspektif ini misalnya cakupan penguasaan keahlian, pendapatan pegawai, dan kepuasan pegawai.

\section{Konsep Value for Money}

Definisi Value for Money berdasarkan Audit Commision dalam Final Report yang disampaikan oleh ITAD, dalam jurnal berjudul Measuring the Impact and Value for Money of Governance \& Conflict Programmes Barnet et al. (2010) mengungkapkan:

"VFM is about obtaining the maximum benefit over time with the resources available. It is about achieving the right local balance between economy, efficiency and effectiveness, or, spending less, spending well and spending wisely to achieve local priorities...VFM is high when there is an optimum balance between all three elements, when costs are relatively low, productivity is high and successful outcomes have been achieved."

Penilaian kinerja berdasarkan value for money menurut Mahmudi (2015) adalah pengukuran kinerja untuk mengukur ekonomi, efisiensi, dan efektivitas suatu kegiatan, program dan organisasi. Pengukuran kinerja value for money merupakan bagian terpenting setiap pengukuran kinerja organisasi sektor publik. Karena pemerintah sebagai wakil rakyat yang dipercaya untuk mengatur dan mengurusi rumah tangga Negara harus mempertanggungjawabkan setiap rupiah yang dikeluarkan. Penilaian kinerja dilakukan untuk mengukur sampai sejauh mana 
akuntabilitas pemerintah dalam membelanjakan dana publik apakah telah memenuhi prinsip ekonomi, efisiensi dan efektivitas.

Value for money menghendaki organisasi bisa memenuhi prinsip ekonomi, efisien, efektivitas tersebut secara bersama-sama. Dengan pengertian lain, value for money menghendaki organisasi dapat mencapai tujuan yang ditetapkan dengan biaya yang lebih rendah. Bila dikaitkan dengan manajemen kinerja berbasis outcome, maka fokus terpenting manajemen kinerja sektor publik adalah pada pencapaian efektivitas. Untuk mencapai efektifitas, organisasi harus efisien. Sebaliknya organisasi yang belum efisien belum tentu efektif.

\section{Konsep Kinerja dan Evaluasi Kinerja}

Yudith Hale (dalam Amir, 2015) menyebutkan bahwa kinerja melibatkan sebuah perspektif yang memperhatikannya pentingnya kebermaknaan dan manfaat dari upaya, hasil yang dicapai dan metode atau cara yang digunakan. John Campbell (dalam Amir, 2015) menyebutkan bahwa kinerja merupakan perilaku atau kegiatan yang relevan dengan tujuan organisasi dan dapat diukur dari sisi tingkat sumbangannya terhadap kecocokan perilaku tertentu dan sejumlah perilaku. Sementara itu, Payaman Simanjuntak (dalam Alimudin et al., 2019) mengemukakan bahwa kinerja merupakan tingkat pencapaian hasil atas pelaksanaan tugas. Menurut Bastian (dalam Mahsina, Poniwarie, and Cholifah, 2017) kinerja adalah gambaran pencapaian pelaksanaan suatu kegiatan / program / kebijakan dalam mewujudkan sasaran, tujuan, misi, dan visi organisasi.

Jadi, kinerja mempunyai makna yang lebih luas bukan hanya menyatakan sebagai hasil kerja tetapi juga bagaimana proses kerja berlangsung dan merupakan implementasi dari rencana yang telah disusun tersebut. Kinerja organisasi ditunjukan oleh bagaimana proses berlangsungnya kegiatan untuk mencapai tujuan tersebut.

Michael Scriven (dalam Wahab, 1997) menyatakan "evaluation is an observed value compared to some standard". Beberapa definisi terakhir ini menyoroti evaluasi sebagai saran-saran untuk mendapatkan informasi yang diperoleh dari proses pengumpulan dan pengolahan data (Yusran, 2006). Evaluasi kinerja menurut Kreitner dan Kinicki (dalam Wibowo, 2013) merupakan pendapat yang bersifat evaluative atas sifat, perilaku seseorang atau prestasi sebagai dasar untuk keputusan dan rencana pengembangan personel. Sementara itu, Newstorm dan Davis memandang sebagai suatu proses mengevaluasi kinerja pekerja, membagi informasi dengan mereka, dan mencari cara memperbaiki kinerjanya. Maksud dilakukannya pengukuran kinerja sektor publik antara lain: untuk membantu memperbaiki kinerja pemerintah agar dapat berfokus pada tujuan dan sasaran program unit kerja yang pada akhirnya akan meningkatkan efisiensi dan efektivitas organisasi sektor publik dalam memberikan layanan kepada masyarakat, untuk mewujudkan tanggung jawab publik dan memperbaiki komunikasi kelembagaan dan untuk pengalokasian sumber daya dan pembuatan keputusan (Septarini dan Silambi, 2015). 


\section{Metode Penelitian}

Penelitian ini bersifat evaluatif dengan pendekatan kuantitatif kualitatif. Lokasi penelitian ini dilakukan di Badan Pengelola Keuangan Aset Daerah Kota Padang. Informan penelitian adalah Kepala Badan Pengelola Keuangan Aset Kota Padang, Kepala Sub Bagian Keuangan, Kepala Bidang Anggaran, Kepala Sub Bidang Pemanfaatan dan Pengamanan Asset, Kepala Sub Bagian Umum dan Kepegawaian dan pegawai Badan Pengelola Keuangan dan Aset Kota Padang. Teknik pengumpulan data dilakukan dengan cara observasi, wawancara dan studi dokumentasi. Pada penelitian ini, teknik pengujian keabsahan data dilakukan dengan menggunakan teknik triangulasi sumber. Alat pengukuran kinerja BPKA peneliti menggunakan metode balanced scorecard dengan menggunakan empat perspektif yaitu perspektif pelanggan, perspektif keuangan dengan pendekatan value for money, perspektif proses internal serta perspektif pertumbuhan dan perkembangan.

\section{Hasil dan Pembahasan}

\section{Pengelolaan Anggaran oleh BPKA Kota Padang}

Rencana kerja perangkat daerah bersumber dari dokumen perencanaan organisasi perangkat daerah untuk periode satu tahun tertentu yang memuat kebijakan, program dan kegiatan pembangunan baik yang dilaksanakan oleh pemerintah daerah maupun yang ditempuh dengan mendorong partisipasi masyarakat. Rencana kerja dijadikan sebagai pedoman rujukan dalam menyusun program dari kegiatan yang telah ditetapkan prioritas pembangunan daerah yang mengarah pada pencapaian sasaran pelayanan yang dalam penyusunannya juga memperhatikan program dan kebijakan pemerintah daerah.

Untuk melaksanakan program kerja tersebut dibutuhkan anggaran yang dapat menunjang agar rencana kerja tadi dapat tercapai dengan baik dan efektif. Pelaksanaan anggaran adalah tahap di mana sumber daya digunakan untuk melaksanakan kebijakan anggaran. Persiapan anggaran yang baik merupakan awal baik secara logis maupun kronologis. Walaupun demikian prosesnya tidaklah sederhana karena adanya mekanisme yang menjamin ketaatan pada programprogram terdahulu. Oleh karena itu pelaksanaan anggaran harus menjamin bahwa anggaran akan dilaksanakan sesuai dengan kewenangan yang diberikan baik dalam aspek keuangan maupun kebijakan, menyesuaikan pelaksanaan anggaran dengan perubahan signifikan dalam kebutuhan satuan kerja perangkat daerah. Pada Badan Pengelola Keuangan dan Aset, anggaran yang dikelola berfungsi untuk menjalankan program-program yang digulirkan setiap tahun dan program tersebut adalah program yang sama setiap tahunnya.

Rancangan anggaran tersebut disusun oleh bidang anggaran pada Badan Pengelola Keuangan Aset Kota Padang. Fungsi dari bidang anggaran ini adalah menyiapkan bahan-bahan penyusunan rancangan anggaran dan merancang berapa anggaran yang dibutuhkan oleh BPKA pertahun anggaran tersebut. Kemudian anggaran tersebut disahkan dan dibelanjakan oleh bidang perbendaharaan. Realisasi dari belanja anggaran tersebut dapat dilihat dari laporan keuangan dan pertanggungjawaban yang dilakukan oleh bidang akuntansi. Pada BPKA juga 
terdapat bidang aset, yang berfungsi mencatat semua aset yang dimiliki oleh kota Padang dan setiap kegiatan yang berhubungan dengan belanja modal dicatat oleh bidang aset dan dihitung sebagai jumlah kekayaan yang dimiliki oleh BPKA.

Semua kegiatan pengelolaan anggaran ini dilakukan sesuai dengan peraturan yang ada yaitu Peraturan Menteri Dalam Negeri Nomor 13 tahun 2016 tentang Pengelolaan Keuangan Daerah. Masing-masing bidang juga diatur oleh peraturan walikota Padang nomor 89 tahun 2016.

\section{Evaluasi Kinerja BPKA Kota Padang}

Dalam BPKA ada yang namanya SKP atau Satuan Kinerja Pegawai untuk melihat apakah kinerja dari pegawai sudah sesuai dengan sasaran yang hendak dicapai atau belum. Untuk melihat sudah tercapai atau belum mereka menggunakan indikator kinerja yang terdiri dari sasaran SKP, kehadiran dan kedisiplinan, persentase kegiatan yang telah dilaksanakan berupa realisasi fisik dan realisasi keuangan.

Untuk melihat sudah tercapai atau belum mereka menggunakan indikator kinerja yang terdiri dari sasaran SKP, kehadiran dan kedisiplinan, persentase kegiatan yang telah dilaksanakan berupa realisasi fisik dan realiasi keuangan. Pada kantor BPKA ini juga, kinerja ditentukan oleh beban kerja yang diberikan pada setiap pegawai. Beban kerja yang ada diakui sangat berat ntuk dilaksanakan apalagi untuk bidang aset yang bertugas mendata seluruh aset yang ada di Kota Padang seperti berapa banyak tanah yang belum memiliki sertifikat di Kota Padang dan lainnya, sehingga memang sangat dibutuhkan tenaga tenaga yang professional dan mengerti di bidangnya. Kinerja dikatakan bagus juga dapat dilihat dari kepuasan OPD yang membutuhkan pelayanan. Tidak hanya itu kepuasan masyarakat juga menjadi acuan disini yaitu masyarakat yang menerima hibah bansos.

Selama ini evaluasi kinerja hanya menilai berdasarkan aspek keuangan saja, sementara lembaga sektor publik seharusnya juga memperhatikan dari sisi internal yaitu pegawai dan eksternal yaitu pelanggan karena lembaga sektor publik bertugas untuk melayani publik. Pengukuran kinerja pada Badan Pengelolaan Keuangan dan Aset Kota Padang ini peneliti lakukan dengan metode balance scorecard. Selama ini pengukuran kinerja hanya berdasarkan tingkat kedisiplinan dan kepatuhan pegawai serta laporan keuangan saja yang dijadikan indikator dalam evaluasi kinerja pegawai di Badan Pengelolaan Keuangan dan Aset kota Padang ini. Sementara untuk balanced scorecard, pada dasarnya mereka sudah mengarah ke konsep tersebut dalam pemakaian istilah saja yang belum.

Untuk perspektif kepuasan pelanggan, angket yang disebarkan sebanyak 30 angket, namun angket yang dikembalikan hanya 16 angket. Begitu juga dengan perspektif proses internal, pertumbuhan dan perkembangan, angket yang peneliti sebarkan ungtuk masing-masing perspektif adalah 92 angket sementara yang dikembalikan hanya 47 angket dari masing-masing perspektif tersebut. Untuk perspektif keuangan yang mengukur efektifitas, efisiensi dan ekonomis dari anggaran tersebut peneliti menggunakan value for money. berikut:

Hasil dari pengolahan data yang peneliti lakukan dapat dilihat sebagai

a. Perspektif Pelanggan. Perspektif pelanggan yang diterapkan di badan pengelola keuangan dan aset cukup baik yaitu sebanyak $62,5 \%$ 
b. Perspektif Proses Internal. Untuk perspektif proses internal dari 92 angket yang disebarkan hanya 47 angket yang dikembalikan. Dan hasilnya adalah 30 angket dari 47 angket tersebut menyatakan bahwa proses internal pada badan pengelola keuangan dan aset ini masih rendah. Dan berarti 63,8\% dari responden tersebut setuju bahwa jika dilihat dari perspektif proses internal belum tercapai dengan baik atau masih rendah. Sementara 17 angket lainnya atau sebanyak 36,2\% mengatakan bahwa tingkat ketercapaian perspektif proses internal sudah baik.

c. Perspektif Pertumbuhan dan Perkembangan. Untuk perspektif pertumbuhan dan perkembangan, angket yang disebarkan sebanyak 92 angket kepada pegawai yang bekerja di Badan Pengelola Keuangan dan Aset kota Padang dan yang dikembalikan hanya 47 angket. Dan hasil pengolahan datanya adalah 25 angket mengatakan bahwa perspektif pertumbuhan dan perkembangan di badan pengelola keuangan dan aset ini masih rendah atau sebanyak 53,19\%. Sementara 22 angket lainnya menyatakan bahwa perspektif pertumbuhan dan perkembangan di badan pengelolaan keuangan dan aset ini sudah baik atau sebanyak 46,81\%.

d. Perspektif Keuangan. Untuk perspektif keuangan peneliti menggunakan Value for Money dalam mengukur perspektif keuangan yaitu dengan mengukur tingkat ekonomi, efektifitas dan efisiensi kinerja BPKA Kota Padang. Jadi, penilaian kinerja BPKA Kota Padang ditinjau dari perspektif keuangan melalui pengukuran tingkat ekonomi, efektivitas dan efisien diperoleh nilai rata-rata 59,76\%, yang artinya bahwa penilaian kinerja BPKA Kota Padang dilihat dari perspektif keuangan adalah baik.

Pada Peraturan Walikota Padang Nomor 44 Tahun 2016 Tentang Pengendalian dan Evaluasi Rencana Strategis dan Rencana Kerja Perangkat Daerah mengatakan bahwa evaluasi adalah rangkaian kegiatan membandingkan realisasi masukan, keluaran dan hasil terhadap rencana dan standar. Sementara evaluasi kinerja merupakan proses yang dilakukan oleh organisasi untuk mengukur dan mengevaluasi perilaku karyawan secara individual dan perilaku kinerja yang dicapai dalam suatu periode tertentu (Kirana, 2017).

Evaluasi kinerja itu perlu dilakukan untuk melihat apakah sasaran yang diinginkan tercapai atau tidak, progresnya seperti apa. Jadi evaluasi kinerja itu merupakan penilaian kinerja baik untuk pegawai maupun badan. Kalau untuk pegawai namanya SKP yaitu Satuan Kinerja Pegawai yang bertugas menilai kinerja dari pegawai BPKA. Evaluasi kinerja proses untuk menilai kinerja pegawai apakah tugas-tugas yang diberikan kepada pegawai sudah dilaksanakan sebaik mungkin atau belum. Tujuannya untuk melihat tingkat pencapaian sasaran yang diharapkan selama ini, jika ditemukan penyimpangan atau ada ketidak sesuaian bisa diperbaiki dan diambil tindakan untuk mencari solusinya.

Evaluasi kinerja pegawai di BPKA dilakukan berdasarkan tingkat kedisiplinan dan kepatuhan pegawai terhadap peraturan yang berlaku. Hasil evaluasi kinerja pegawai ini nantinya yang dijadikan acuan dalam melakukan penilaian terhadap kinerja Badan Pengelola Keuangan dan Aset. Selama ini penilaian kinerja terhadap suatu badan hanya dilihat berdasarkan laporan keuangan saja sementara birokrasi itu bertugas untuk memberikan pelayanan terhadap publik 
sehingga dibutuhkan sistem penilaian kinerja yang berorientasi pada kepuasan publik sehingga dibutuhkan pengukuran kinerja yang berkualitas dan handal dengan menggunakan instrument sistem pengukuran yang mampu mencerminkan kinerja suatu badan dengan baik, dalam hal ini untuk sektor publik menggunakan LAKIP (Laporan Akuntabilitas Kinerja Instansi Pemerintah) dan hanya mengukur dari sisi keuangan saja. Sehingga tidak memperhatikan sektor internal dan eksternal dari badan tersebut. Peneliti telah melakukan evaluasi terhadap kinerja BPKA Kota Padang dengan balanced scorecard dengan menggunakan empat perspektif dan hasilnya telah peneliti jabarkan sebelumnya.

Badan Pengelola Keuangan dan Aset Kota Padang ini telah menerapkan balanced scorecard yaitu dengan berusaha memperbaiki beberapa hal dalam segi pelayanan kepada publik karena kurang tersedianya sarana dan prasarana yang mendukung pelayanan publik seperti kondisi gedung yang kurang representative, dan hal tersebut juga diakui oleh pegawai yang bekerja di BPKA Kota Padang dan beberapa pejabat BPKA Kota Padang. Tidak hanya itu, ruang tunggu pelayanan yang tidak ada dan membuat suasana kurang nyaman juga perlu dibenahi lagi karena itu juga merupakan indikator dalam pelayanan publik.

\section{Faktor yang Mempengaruhi Pengelolaan Anggaran di BPKA Kota Padang}

Agar pengelolaan anggaran ini berjalan sebagaimana mestinya ada faktor-faktor yang mempengaruhi dalam pengelolaan anggaran. Faktor pendukung dalam pengelolaan anggaran itu adalah adanya pegawai yang berkompeten di bidangnya, adanya anggaran yang akan dikelola, adanya peraturan yang jelas dan dokumen pelaksana serta informasi teknologi. Dalam pengelolaan anggaran agar kinerjanya cepat, tepat dan akurat dibutuhkan dukungan teknologi informasi yang baik dan juga kecakapan pegawai BPKA dalam menggunakan teknologi informasi tersebut. Jadi semua pegawai harus melek informasi, melek teknologi. Untuk BPKA sendiri penggunaan server yang baik sangat mendukung kinerja dari BPKA, sehingga informasi tentang BPKA akan mudah juga diakses oleh organisasi perangkat daerah lainnya serta masyarakat luas dan ini juga menunjukkan bahwa BPKA itu transparan dalam pengelolaan anggaran. Dan untuk meminimalisir komplain dari organisasi perangkat daerah yang membutuhkan pelayanan dari BPKA.

Dalam melakukan pengelolaan anggaran terdapat faktor-faktor yang mempengaruhi pengelolaan anggaran tersebut. Sebelumnya sudah dijelaskan bahwa berdasarkan wawancara yang telah peneliti lakukan bahwa faktor-faktor yang mempengaruhi dalam pengelolaan anggaran ini ada empat yaitu: a) Sumber daya aparatur yang memiliki kompetensi di bidangnya. b) Adanya peraturan yang jelas, c) Adanya dokumen pelaksana, d) Adanya anggaran yang akan dikelola.

Menurut Pekei (2016) faktor-faktor yang mempengaruhi dalam pengelolaan anggaran adalah sebagai berikut: 1) Sarana dan prasarana serta peralatan kerja yang memadai dan digunakan dalam proses pengelolaan anggaran, b) Kualitas dan kuantitas sumber daya manusia, c) Adanya anggaran yang cukup untuk dikelola, d) Struktur dan mekanisme kerja yang jelas, e) Adanya komitmen yang tinggi dari pejabat yang akan mengelola anggaran tersebut agar tercapainya efektifitas, efisiensi dan ekonomi dalam pengelolaan anggaran, f) Adanya sistem 
komputerisasi yang optimal, g) Pengawasan dari pihak terkait untuk meminimalisir penyimpangan dari proses pengelolaan anggaran tersebut

Jadi dapat disimpulkan bahwa banyak faktor yang mempengaruhi dalam pengelolaan anggaran tersebut. Tapi faktor yang mempengaruhi menurut peneliti adalah kemampuan pegawai dalam mengelola anggaran tersebut yang paling berpengaruh. Karena apabila pegawai yang mengelola anggaran tersebut tidak kompeten di bidangnya maka anggaran yang dikelola tidak akan efektif dan efisien. Namun apabila pegawai yang mengelola anggaran tersebut memiliki kemampuan di bidangnya maka akan tercipta pengelolaan anggaran yang kondusif dan sesuai dengan sasaran yang akan dicapai.

Dalam pengelolaan anggaran selain faktor pendukung, tentu terdapat hambatan-hambatan serta tantangan. Begitu juga dengan yang dialami oleh badan pengelola keuangan dan Aset kota Padang, kurangnya sumber daya aparatur yang memiliki kompetensi dan kemampuan dalam pengelolaan keuangan dan anggaran juga merupakan hambatan yang dimiliki BPKA dalam pengelolaan anggaran. Hal ini dibuktikan dengan terdapatnya 84 orang pegawai dari 183 pegawai yang ada atau sebanyak 45,90\% hanya lulusan sekolah menengah atas. Beban kerja yang berat dan tidak sesuai dengan banyaknya aparatur di BPKA juga merupakan tantangan dari pengelolaan anggaran di BPKA Kota Padang. Dalam 2 tahun belakangan ini beban kerja yang dimiliki BPKA sangat berat, jam kerja tidak sesuai dengan ketentuan apalagi pada saat merancang anggaran semua pegawai BPKA Kota Padang bisa sampai 24 jam berada di kantor. Apalagi jika menerima komplain dari pelanggan khususunya OPD yang bermaksud meminta dana, pegawai BPKA harus berada ditempat menunggu perwakilan OPD tersebut datang dan terkadang harus sampai jam 19.00 WIB.

\section{Upaya BPKA dalam Menghadapi Tantangan dan Hambatan dalam Pengelolaan Anggaran}

Upaya-upaya yang dilakukan dalam menghadapi tantangan dan hambatan dalam pengelolaan anggaran tadi, Badan Pengelola Keuangan dan Aset melakukan beberapa tindakan, antara lain melalui kegiatan bimtek, sosialisasi, dan pelatihan kepada pegawai. Selain itu upaya juga dilakukan dengan melakukan "rolling" atau mutasi kepada seluruh pegawai agar semua pegawai memiliki kemampuan untuk menyelesaikan pekerjaan tidak hanya pada satu bidang saja. Informan lain juga mengatakan bahwa upaya yang dilakukan adalah dalam bentuk meningkatkan budaya kerja yang baik seperti disiplin pegawai lebih ditingkatkan lagi, mutasi internal sekali setahun supaya tidak jenuh dan bisa mengerjakan pekerjaan disegala bidang. Penempatan pegawai berdasarkan beban kerja juga merupakan upaya lain yang dilakukan oleh pimpinan BPKA. Jadi, dapat disimpulkan bahwa Badan Pengelola Keuangan dan Aset telah melakukan berbagai upaya dalam pengelolaan anggaran antara lain adalah dengan penempatan pegawai berdasarkan beban kerja, perbaikan kualitas server, peningkatan disiplin dan kepatuhan pegawai, serta melakukan bimbingan teknis kepada semua pegawai dan mutasi internal pada seluruh pegawai dan lain-lain.

Menurut Mardiasmo (2010), anggaran merupakan pernyataan mengenai estimasi kinerja yang hendak dicapai selama periode waktu tertentu yang 
dinyatakan dalam ukuran finansial, sedangkan penganggaran adalah proses atau metode untuk mempersiapkan suatu anggaran. Pada prinsipnya anggaran merupakan suatu rencana keuangan yang mencerminkan semua unsur kegiatan operasional dalam suatu perusahaan atau lembaga secara terperinci. Oleh karena itu diperlukan koordinasi serta pengawasan agar pelaksanaan dari rencana tersebut tidak menyimpang dari yang telah direncanakan sebelumnya.

Anggaran memiliki peranan penting dalam perencanaan, pengendalian, dan evaluasi aktivitas yang dilakukan oleh pemerintah. Karena anggaran memiliki kedudukan penting, suatu unit pemerintah harus mencatat anggaran serta melaporkan realisasinya sehingga dapat diperbandingkan selisih antara anggaran dengan pelaksanaan serta melakukan tindak lanjut perbaikan.

Sistem anggaran pada dasarnya merupakan sistem yang mencakup kegiatan penyusunan program dan tolok ukur kinerja sebagai instrumen untuk mencapai tujuan dan sasaran program. Penetapan sistem anggaran dalam penyusunan anggaran dimulai dengan perumusan program dan penyusunan struktur organisasi pemerintah yang sesuai dengan program tersebut. Kegiatan tersebut mencakup pula penentuan unit kerja yang bertanggung jawab atas pelaksanaan program, serta penentuan indikator kinerja yang digunakan sebagai tolok ukur dalam mencapai tujuan program yang telah ditetapkan berdasarkan perencanaan yang telah dibuat.

Anggaran tersebut memiliki banyak fungsi yaitu sebagai alat perencanaan untuk merumuskan tujuan serta sasaran kebijakan agar sesuai dengan visi dan misi yang ditetapkan dan juga untuk menentukan indikator kinerja dan tingkatan pencapaian serta strategi pencapaian. Kemudian anggaran juga berfungsi sebagai alat pengendali yang memberikan rencana detail atas pendapatan dan pengeluaran agar dapat dipertanggungjawabkan penggunaannya kepada publik (Pekei, 2016).

Perencanaan dapat dikatakan sebagai suatu upaya institusi publik untuk membuat arah kebijakan pembangunan yang harus dilakukan di sebuah wilayah baik negara atau daerah dengan didasarkan keunggulan dan kelemahan yang dimiliki oleh wilayah tersebut. Sedangkan anggaran merupakan pernyataan mengenai estimasi kinerja yang hendak dicapai selama periode waktu tertentu yang dinyatakan dalam ukuran finansial, sedangkan penganggaran adalah proses atau metode untuk mempersiapkan suatu anggaran. Perencanaan dan penganggaran merupakan proses yang terintegrasi, oleh karenanya output dari perencanaan adalah penganggaran. Perumusan program di dalam perencanaan pada akhirnya berimplikasi pada besarnya kebutuhan anggaran yang harus disediakan, sehingga keberhasilan penggunaan anggaran dimulai dari perencanaannya.

Menurut S. Daranatha (2009) sistem adalah sekelompok dua atau lebih komponen-komponen yang saling berkaitan yang bersatu untuk mencapai tujuan yang sama yang dikoordinasikan untuk menyelesaikan suatu sasaran tertentu agar mempermudah bagi yang membuat dan bagi yang menggunakan suatu sistem. Sistem anggaran pada dasarnya merupakan sistem yang mencakup kegiatan penyusunan program dan tolok ukur kinerja sebagai instrumen untuk mencapai tujuan dan sasaran program. Penetapan sistem anggaran dalam penyusunan anggaran dimulai dengan perumusan program dan penyusunan struktur organisasi pemerintah yang sesuai dengan program tersebut. Kegiatan tersebut mencakup pula penentuan unit kerja yang bertanggung jawab atas pelaksanaan program, serta 
penentuan indikator kinerja yang digunakan sebagai tolok ukur dalam mencapai tujuan program yang telah ditetapkan berdasarkan perencanaan yang telah dibuat.

\section{Penutup}

Berdasarkan hasil penelitian yang telah diuraikan sebelumnya maka dapat ditarik kesimpulan:

a) Setelah dilakukan evaluasi kinerja pada Badan Pengelola Keuangan dan Aset dengan balanced scorecard dan value for money maka dapat disimpulkan bahwa penerapan metode balance scorecard belum maksimal dilakukan di Kantor BPKA Kota Padang ini. Jika dilihat berdasarkan persepektif pelanggan diperoleh hasil sebanyak $62,5 \%$ yang menyatakan bahwa usaha dalam meningkatkan kepuasan publik terhadap kinerja Badan Pengelola Keuangan dan Aset cukup baik. Sementara pada perspektif proses internal belum tercapai dengan baik atau masih rendah yaitu sebanyak $63,8 \%$ yang menyatakan bahwa peningkatan dalam proses internal masih perlu banyak pembenahan. Dan pada perspektif pertumbuhan dan perkembangan diperoleh hasil sebanyak 53,8\% yang menyatakan bahwa proses pertumbuhan dan perkembangan belum tercapai dengan baik atau masih rendah. Pada perspektif keuangan menggunakan teknik value for money untuk melihat ekonomi, efisien dan efektif dalam pengelolaan anggaran, hasil penelitian ini menunjukan bahwa keuangan BPKA Kota Padang untuk tingkat ekonomi mengalami kenaikan dalan dua tahun terakhir dan sudah cukup ekonomis sehingga penggunaan anggaran sangat hemat karena realisasi belanja selalu lebih kecil jika dibandingkan dengan anggaran belanja yang telah ditetapkan yaitu sebesar 78,75\%. Sementara dari segi efisien, hasil penelitian menunjukan bahwa secara keseluruhan diperoleh persentase kurang dari $100 \%$ yaitu dengan rata rata $24,75 \%$ artinya pengukuran tingkat efisiensi BPKA Kota Padang dikatakan efisien, berdasarkan hasil penelitian tersebut menunjukan bahwa kinerja keuangan BPKA efektif karena realisasi pendapatan yang berhasil dicapai jika dibandingkan dengan target pendapatan yang diberikan berada pada persentase di atas $70 \%$. Jadi, dapat disimpulkan bahwa penilaian kinerja BPKA Kota Padang ditinjau dari perspektif keuangan melalui pengukuran tingkat ekonomi, efektivitas dan efisien diperoleh nilai rata-rata 59,76\%, yang artinya bahwa penilaian kinerja BPKA Kota Padang dilihat dari perspektif keuangan adalah termasuk kategori baik, belum sangat baik.

b) Faktor yang mempengaruhi dalam pengelolaan anggaran di Badan Pengelola Keuangan dan Aset adalah sarana dan prasarana serta peralatan kerja yang memadai dan digunakan dalam proses pengelolaan anggaran, kualitas dan kuantitas sumber daya manusia, adanya anggaran yang cukup untuk dikelola, struktur dan mekanisme kerja yang jelas, adanya komitmen yang tinggi dari pejabat yang akan mengelola anggaran tersebut agar tercapainya efektifitas, efisiensi dan ekonomi dalam pengelolaan anggaran, adanya sistem komputerisasi yang optimal, pengawasan dari pihak terkait untuk meminimalisir penyimpangan dari 
proses pengelolaan anggaran tersebut. Sementara tantangan yang dihadapi dalam pengelolaan anggaran adalah Beban kerja yang sangat berat, kondisi masyarakat yag semakin kritis terhadap perubahan, kondisi gedung belum representative, sumber daya aparatur yang belum memadai dalam pengelolaan keuangan daerah.

c) Upaya yang dilakukan BPKA Kota Padang dalam menghadapi tantangan dalam pengelolaan anggaran adalah penempatan pegawai berdasarkan beban kerja, perbaikan kualitas server, peningkatan disiplin dan kepatuhan pegawai, serta melakukan bimbingan teknis kepada semua pegawai dan mutasi internal pada seluruh pegawai.

\section{DAFTAR KEPUSTAKAAN}

Agustina, Oesi. 2013. “Analisis Kinerja Pengelolaan Keuangan Daerah Dan Tingkat Kemandirian Daerah Di Era Otonomi Daerah Studi Kasus Kota Malang." Universitas Brawijaya.

Alimudin, Arasy, Achmad Zakki Falani, Sri Wiwoho Mudjanarko, and Arthur Daniel Limantara. 2019. "Analisis Pengaruh Penerapan Perspektif Balanced Scorecard Terhadap Peningkatan Kinerja UMKM.” Jurnal Ekonomi Universitas Kadiri 4 No 1:1-17.

Amir, Mohammad Faisal. 2015. Memahami Evaluasi Kinerja Karyawan. Jakarta: Mitra Wacana Media.

Barnet, Chris, Julian Bar, Angela Christie, Belinda Duff, and Shaun Heft. 2010. Measuring The Impact and Value for Money of Governance and Conflict Programmes.

Dorf, R. C., and M. Raitanen. 2005. "The Balanced Scorecard: Translating Strategy Into Action." Proceedings of the IEEE 85(9):1509-10.

Halim, Abdul. 2001. Akuntansi Sektor Publik-Akuntansi Keuangan Daerah. Jakarta: Salemba Empat.

Kaplan, Robert S., and David P. Norton. 2001. "Accounting Horizons Vol." 15(2):147-60.

Kirana, Kusuma Candra. 2017. Evaluasi Kinerja Sumber Daya Manusia. Yogyakarta: Gosyen Publishing.

Mahmudi. 2015. Manajemen Kinerja Sektor Publik Edisi Kedua. Yogyakarta: UPP STIM YKPN.

Mahsina, Asmie Poniwarie, and Cholifah. 2017. "Analisis Penerapan Balanced Scorecard, Alat Ukur Penilaian Kinerja Pada Dinas Pendapatan, Pengelolaan Keuangan Dan Aset Kabupaten Sidoarjo.” Maksi Preneur VII(1):59-72.

Mardiasmo. 2010. Otonomi Dan Manajemen Keuangan Daerah. Yogyakarta: ANDI.

Mizkan, Hendra, Kamaliah, and Restu Agusti. 2015. “Analisis Kinerja Pengelolaan Keuangan Daerah Dan Pengaruhnya Terhadap Tingkat Kemiskinan Di Kota Pekanbaru." Jurnal Sorot, Lembaga Penelitian Dan Pengabdian Kepada Masyarakat 10 No 1.

Nor, Wahyudin. 2012. "Penerapan Balanced Scorecard Pada Pemerintah Daerah." 
Jurnal Akuntansi Dan Bisnis AUDI 7 No 2.

Pekei, Beni. 2016. Konsep Dan Analisis Efektifitas Pengelolaan

KeuanganDaerah Di Era Otonomi. Pertama. Jayapura: Taushia.

S., Daranatha. 2009. Sistem Informasi Akuntansi. Jakarta: Salemba Empat.

Septarini, Dina Fitri, and Erni Dwita Silambi. 2015. "Analisis Kinerja Aparatur

Pemerintah Menggunakan Pendekatan Balanced Scorecard Studi Kasus Pada

Aparatur Pemerintah Di Kampun Yanggandur.” Jurnal Ilmu Ekonomi Dan Sosial VI No 2.

Suoth, Novelya, Jantje Tinangon, and Sintje Rondonuwu. 2016. "Pengukuran Efisiensi Dan Efektifitas Pengelolaan Keuangan Daerah Pada Dinas Pengelolaan Keuangan, Pendapatan Dan Aset (DPKA) Kabupaten Minahasa Selatan." Jurnal EMBA 4 No 1:613-22.

Wahab, Solichin Abdul. 1997. Evaluasi Kebijakan Publik, Konsep, Tipologi Dan Strategi Pemanfaatannya. Malang: IKIP Malang.

Wibowo. 2013. Manajemen Kinerja. Jakarta: Rajawali Pers.

Yasin, Stepanus. 2008. "Analisis Kinerja Keuangan Pemerintah Daerah Menggunakan Metode Value For Money.” Universitas Sanata Dharma.

Yusran, Rahmadhani. 2006. Buku Ajar Kebijakan Publik. Padang: Universitas Negeri Padang. 